\title{
Determination of seasonal changes of spider mite (Acari: Tetranychidae) den- sities and species composition on kudzu vine and soybean (Fabaceae) in Japan with the use of phosphoglucomutase zymograms*
}

\author{
TETSUO GOTOH ${ }^{1} \&$ KATSUHIKO MORI ${ }^{2}$ \\ 'Laboratory of Applied Entomology and Zoology, Faculty of Agriculture, Ibaraki University, Ami, Ibaraki 300-0393, Japan; \\ E-mail: gotoh@mx.ibaraki.ac.jp \\ ${ }^{2}$ Kochi Experiment Station of Research Institute of Japan Plant Protection Association, Konan, Kochi 781-5231, Japan; \\ E-mail:mori@jppa.or.jp
}

* In: Moraes, G.J. de \& Proctor, H. (eds) Acarology XIII: Proceedings of the International Congress. Zoosymposia, 6, 1-304.

\begin{abstract}
Identification of spider mites based on morphological characteristics is difficult because morphological differences between species may be subtle and in some groups, including the Tetranychus Dufour species, detectable only in adult males, which usually correspond to a small proportion of a population. The utility of an alternative method, phosphoglucomutase (PGM) zymogram, is demonstrated in this study. Using this method, we were able to discriminate females of each of 13 known Japanese Tetranychus species. We examined the species composition and seasonal density changes on kudzu vine [Pueraria montana var. lobata (Willd.) Sanjappa and Pradeep], a fabaceous weed, between 1997 and 1999, and on soybean [Glycine $\max$ (L.)] between 1999 and 2001. On kudzu vine, spider mite populations showed two types of seasonal fluctuation, one characterized by a single peak in September or October and the other by two peaks, in June and September. Five spider mite species were found on this plant species, with $T$. pueraricola Ehara \& Gotoh being dominant throughout the 3-year period and accounting for 75.6-96.9\% of all females. On soybean, spider mite populations showed three types of seasonal fluctuation, characterized by one peak (August), two peaks (August, November), and three peaks (June, August, October), respectively. On this plant, eight species were found, T. pueraricola being dominant in 1999 (54.7\%), T. parakanzawai Ehara in $2000(72.6 \%)$ and T. kanzawai Kishida in $2001(69.2 \%)$. Such annual variation in dominance was probably determined by the order of invasion of soybean fields.
\end{abstract}

Key words: Species composition, population dynamics, Pueraria montana var. lobata, soybean, Tetranychidae.

\section{Introduction}

Species identification of spider mites has important implications for accurate control, population dynamics studies and resolving international trade barriers related to plant quarantine (Kitashima \& Gotoh, 1997; Osakabe et al., 2002). A number of methods has been used for species identification, based mainly on the morphological characteristics of adults (Ehara, 1999; Ehara \& Gotoh, 2009), ribosomal DNA (rDNA) polymorphisms (Navajas et al., 1997, 2001) and restriction fragment-length polymorphism following PCR (PCR-RFLP) (Gotoh et al., 1998; Osakabe et al., 2002). However, each of these methods has some disadvantages. Species identification based on morphological characteristics observed under phase-contrast microscopy is difficult because the mites are very small, differences are often subtle and the collected individuals may not be of the sex or developmental stage that has the known relevant morphological characteristics. In some groups, including the Tetranychus Dufour species, differences are usually only known in adult males, which may be hard to find. DNA sequencing is expensive and labor intensive and, as a result, may not allow the comparison of a large number of individuals (Hance et al., 1998). 
An alternative to avoid those difficulties is to examine enzymatic differences (zymograms or banding patterns of enzymes). Many studies have used zymograms of various enzymes, such as esterase, phosphoglucoisomerase (PGI) and malate dehydrogenase (MDH), to discriminate mite species (Gotoh \& Ishikawa, 1992; Gotoh \& Takayama, 1992; Enohara \& Amano, 1996; Goka \& Takafuji, 1997; Kitashima \& Gotoh, 1997; Gotoh et al., 2007b). Enzymatic differentiation can be difficult when intraspecific variation occurs in banding patterns (polymorphic alleles) and when common bands are observed among distinct species (Goka \& Takafuji, 1997). However, if an enzyme with diagnostic banding pattern can be found, this method can be used to inexpensively treat hundreds of individuals in just a few hours. Our experiments indicated that phosphoglucomutase (PGM) zymograms could discriminate some Tetranychus species (Gotoh, unpub. results). Many studies have been conducted to identify phytophagous arthropods on weeds, mainly for the search of promising biological control agents of those weeds (Goeden, 1971, 1974; Zwölfer, 1988; Forester, 1993; Wilson \& Flanagan, 1993; Jobin et al., 1996; Imura, 2003). The kudzu vine, Pueraria montana var. lobata (Willd.) Sanjappa \& Pradeep, is considered a harmful invasive weed in parts of North America (Williamson, 1996). The vine extends 9-35 m per year and surrounds other plant stems and tree trunks, in some cases killing them (Duke \& Reed, 1981). Some spider mite species infest kudzu in Japan, but little is known about the composition and structure of mite species on the plant.

Kudzu vine is native to and distributed throughout Japan, where it has been exploited successfully by at least six red-pigmented Tetranychus species: T. ludeni Zacher, T. kanzawai Kishida, $T$. parakanzawai Ehara, T. piercei McGregor, T. pueraricola Ehara \& Gotoh, and the red form of $T$. urticae Koch. Four of these species (T. kanzawai, T. ludeni, T. piercei and T. urticae) are known to be pests of agricultural crops (Bolland et al., 1998; Ehara \& Gotoh, 2009). The objective of this study was to determine the composition and population dynamics of Tetranychus species on kudzu in comparison to soybean [Glycine max (L.)] as an example of an agricultural crop of the same plant family as kudzu (Fabaceae), while also evaluating the suitability of PGM zymograms to identify the spider mite species collected. Four tetranychids (T. kanzawai, T. ludeni, T. phaselus Ehara and T. urticae) have been recorded as pests of soybean in Japan, but the knowledge is fragmentary (Japanese Society of Applied Entomology and Zoology, 2006).

\section{Materials and Methods}

\section{Mites}

Thirteen red-pigmented Tetranychus species were collected from various locations in Japan from 1993 to 2005 (see details in Gotoh et al., 2007b). A colony of each species was kept at $25 \pm$ $1{ }^{\circ} \mathrm{C}$ under a 16L: $8 \mathrm{D}$ photoperiod in the laboratory, on discs of leaves of different plants, as follows: mulberry (Morus bombycis Koidz.) for T. ezoensis Ehara, a solanaceous weed (Solanum nigrum L.) for T. evansi Baker and Pritchard (= T. takafujii Ehara \& Ohashi; Gotoh et al., 2009), or common bean (Phaseolus vulgaris L.) for the other species.

\section{Electrophoresis and enzyme staining}

Individual frozen females or males were homogenized in $10 \mu \mathrm{L}$ of $32 \%(w / v)$ sucrose with $0.1 \%$ Triton X-100 and $0.002 \%$ bromophenol blue. Aliquots of $10 \mu \mathrm{L}$ of the homogenate were subjected to polyacrylamide vertical slab electrophoresis. The gels were $1 \mathrm{~mm}$ thick, $145 \mathrm{~mm}$ wide and $160 \mathrm{~mm}$ high, and contained Triton X-100 (concentration $0.05 \%$ in the separating gels and $0.1 \%$ in the stacking gels). The concentration of acrylamide was $6.0 \%$ for the separating gels and $2.5 \%$ for the stacking gels. Electrophoresis was carried out at a constant current of 20 $\mathrm{mA} / \mathrm{gel}$ at $5^{\circ} \mathrm{C}$ for $3 \mathrm{~h}$. To stain for PGM, gels were placed in $0.1 \mathrm{M}$ Tris-HCl buffer $(\mathrm{pH} \mathrm{8.0)}$ 
with $0.08 \%$ of disodium DL-malate, $0.02 \%$ nitro blue tetrazolium and $0.01 \%$ phenazine methosulphate for $40 \mathrm{~min}$ at $35^{\circ} \mathrm{C}$. Bands of species with more than one rate of mobility (i.e., isoforms) were referred to as F- and S-alleles, respectively. To separate females using PGM banding patterns, we used two pairs of mites as diagnostic markers (i.e., marker species): one pair consisted of one female T. ludeni carrying the S-allele and one red form female of T. urticae carrying the F-allele, and the other pair consisted of one female T. parakanzawai and one female T. pueraricola. As S-allele homozygous females were prevalent in T. ludeni, whereas F-allele homozygous females were extremely dominant in T. urticae (Gotoh et al., 2007b), we chose females carrying these alleles to differentiate field-collected females. The marker species of the genus Tetranychus were separately reared at $25^{\circ} \mathrm{C}$ and $16 \mathrm{~L}: 8 \mathrm{D}$ in the laboratory on leaf discs of the common bean.

In our preliminary test, we observed no difference in banding patterns between the mite samples kept on leaves of common bean and those kept on kudzu vine or soybean leaves for more than two generation (data not shown); therefore, we used common bean leaves for rearing mites sampled from kudzu vine and soybean. Each allele was expressed in terms of the electrophoretic mobility of each band relative to that of the tracking dye (bromophenol blue). Mobility was determined using 1,000 horizontal lines after entering gels into a computer, as shown in Fig. 1. The center of the band was used to determine mobility.

\section{Study sites and sampling}

Two plots of kudzu vine were chosen for the study, Tsuchiura (site A; $36^{\circ} 03^{\prime} \mathrm{N} ; 140^{\circ} 12^{\prime} \mathrm{E}$ ) and Tsukuba (site B; $36^{\circ} 05^{\prime} \mathrm{N} ; 140^{\circ} 04^{\prime} \mathrm{E}$ ) in Ibaraki Prefecture, central Japan. These sites were located in residential areas that had several small truck farms. An area of 10 x 10 m was set up at each site and divided into $1001 \mathrm{x} 1 \mathrm{~m}$ neighboring subplots. Kudzu vine leaves almost totally covered the plots in mid-summer. For soybean, one agrochemical unsprayed plot was chosen in a soybean field as the study site; it was located in Ushiku $\left(35^{\circ} 58^{\prime} \mathrm{N}\right.$; $\left.140^{\circ} 10^{\prime} \mathrm{E}\right)$ in Ibaraki Prefecture (Mori et al., 2008). An area of $8 \times 12.5 \mathrm{~m}$ was set up in this field and divided into $501.25 \times 1.6 \mathrm{~m}$ subplots.

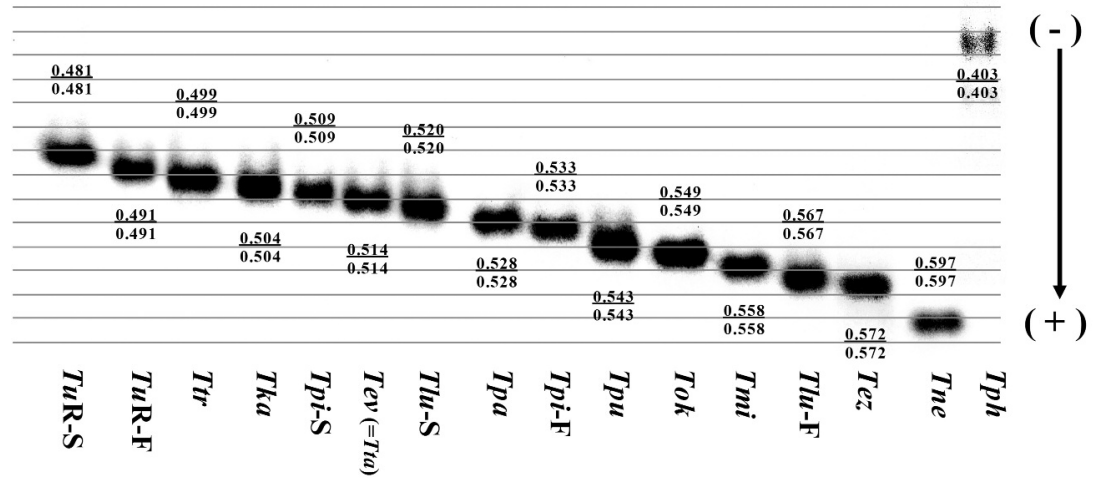

FIGURE 1. Phosphoglucomutase (PGM) zymograms of adult females of 13 Japanese species of Tetranychus. "S" and "F" indicate the alleles with slow and fast mobilities, respectively. Each allele is expressed in terms of the electrophoretic mobility of each band relative to that of the tracking dye (bromophenol blue). Horizontal lines are level markers. Two pairs of mites were used as diagnostic markers for separating females: one pair consisted of one female T. ludeni (S-allele) and one female T. urticae (F-allele) and the other pair consisted of one female T. parakanzawai and one female T. pueraricola. Species listed next to the corresponding phenotypes: TuR: T. urticae (red form); Ttr: T. truncatus; Tka: T. kanzawai; Tpi: T. piercei; Tev: T. evansi; Tta: T. takafujii; Tlu: T. ludeni; Tpa: T. parakanzawai; Tpu: T. pueraricola; Tok: T. okinawanus; Tmi: T. misumaiensis; Tez: T. ezoensis; Tne: T. neocaledonicus; Tph: T. phaselus (Modified from Gotoh et al., 2007b). 
Kudzu vine leaves are composed of three leaflets whose length and width are about $10-15 \mathrm{~cm}$ each. One of the three leaflets of a kudzu vine leaf was sampled from each subplot at 10-day intervals, from late April, just before the occurrence of leaf flush, to late November, just after complete foliage abscission, from 1997 to 1999. Two of three leaflets of a soybean leaf were sampled from each subplot at 7-day intervals, from mid June to late November, from 1999 to 2001. Leaflets of each subplot were put into a separate vinyl bag and kept under a layer of ice in an ice chest. Within a few hours, the samples were placed in a refrigerator in the laboratory. All stages of spider mites, predators, and phytophagous thrips on soybean leaflets were counted under a dissecting microscope within two days after sampling. All adult female spider mites sampled from kudzu vine and soybean leaflets were placed individually onto leaf discs $\left(\mathrm{ca} .4 \mathrm{~cm}^{2}\right)$ of common bean and allowed to oviposit for three days at $25^{\circ} \mathrm{C}$ and $16 \mathrm{~L}$ : $8 \mathrm{D}$, after what they were stored individually at $-80^{\circ} \mathrm{C}$ until used in the electrophoresis (less than three months). The progeny were then reared to the adult stage ( $\mathrm{F}_{1}$ adults $)$ at the same conditions of temperature and photoperiod. $\mathrm{F}_{1}$ adult females and males were prepared for the morphological study. If only a few $\mathrm{F}_{1}$ males were produced, then $\mathrm{F}_{1}$ females and males were mated and their progeny were reared to obtain males of the next $\left(\mathrm{F}_{2}\right)$ generation, for the morphological study. If oviposition did not occur or only male progeny were produced, data of the collected females were discarded (Gotoh et al., 2007a, b).

\section{Results}

\section{Spider mite identification}

In the zymograms, none of the species shared bands with identical mobility (Fig. 1). Thus, PGM zymograms were consistent with the morphological characteristics of laboratory stocks as well as with field samples collected from kudzu vine and soybean [data not shown; see Gotoh et al. (2007b) and Mori et al. (2008) for details], although females of T. ludeni, T. piercei and red form of T. urticae showed two bands (S-and F-alleles). On both plants, the allele frequencies were closely similar: S-allele homozygous females were dominant in T. ludeni, whereas F-allele females were prevalent in T. piercei and T. urticae.

\section{Seasonal changes of spider mite density and species composition on kudzu vine}

Spider mite populations peaked in June (spring peak) and/or in September-October (autumn peak) at both site A (Fig. 2A) and site B (Fig. 2B). Predators observed on kudzu vine at both sites were phytoseiid and stigmaeid mites (Table 1), Scolothrips takahashii Priesner (Thripidae),

TABLE 1. Phytoseiidae and Stigmaeidae mites observed on kudzu vine at two study sites from 1997 to 1999. Values indicate the total number of female adults identified in each year.

\begin{tabular}{|c|c|c|c|c|c|c|}
\hline \multirow[t]{2}{*}{ Species } & \multicolumn{3}{|c|}{ Site A } & \multicolumn{3}{|c|}{ Site B } \\
\hline & 1997 & 1998 & 1999 & 1997 & 1998 & 1999 \\
\hline Phytoseiidae & 3 & 173 & 8 & 0 & 5 & 1 \\
\hline Amblyseius tsugawai Ehara & 29 & 89 & 7 & 121 & 43 & 3 \\
\hline Phytoseius nipponicus Ehara & 20 & 25 & 14 & 29 & 0 & 0 \\
\hline Neoseiulus womersleyi (Schicha) & 1 & 9 & 0 & 1 & 3 & 0 \\
\hline Scapulaseius okinawanus (Ehara) & 0 & 1 & 5 & 0 & 1 & 3 \\
\hline Amblyseius eharai Amitai \& Swirski & 0 & 3 & 0 & 1 & 0 & 0 \\
\hline Euseius sojaensis (Ehara) & 0 & 0 & 0 & 1 & 0 & 0 \\
\hline Typhlodromus vulgaris (Ehara) & 0 & 0 & 0 & 0 & 1 & 0 \\
\hline \multicolumn{7}{|l|}{ Stigmaeidae } \\
\hline Agistemus exsertus Gonzalez & 5 & 0 & 0 & 0 & 0 & 0 \\
\hline Agistemus terminalis (Quayle) & 0 & 3 & 0 & 0 & 0 & 0 \\
\hline
\end{tabular}



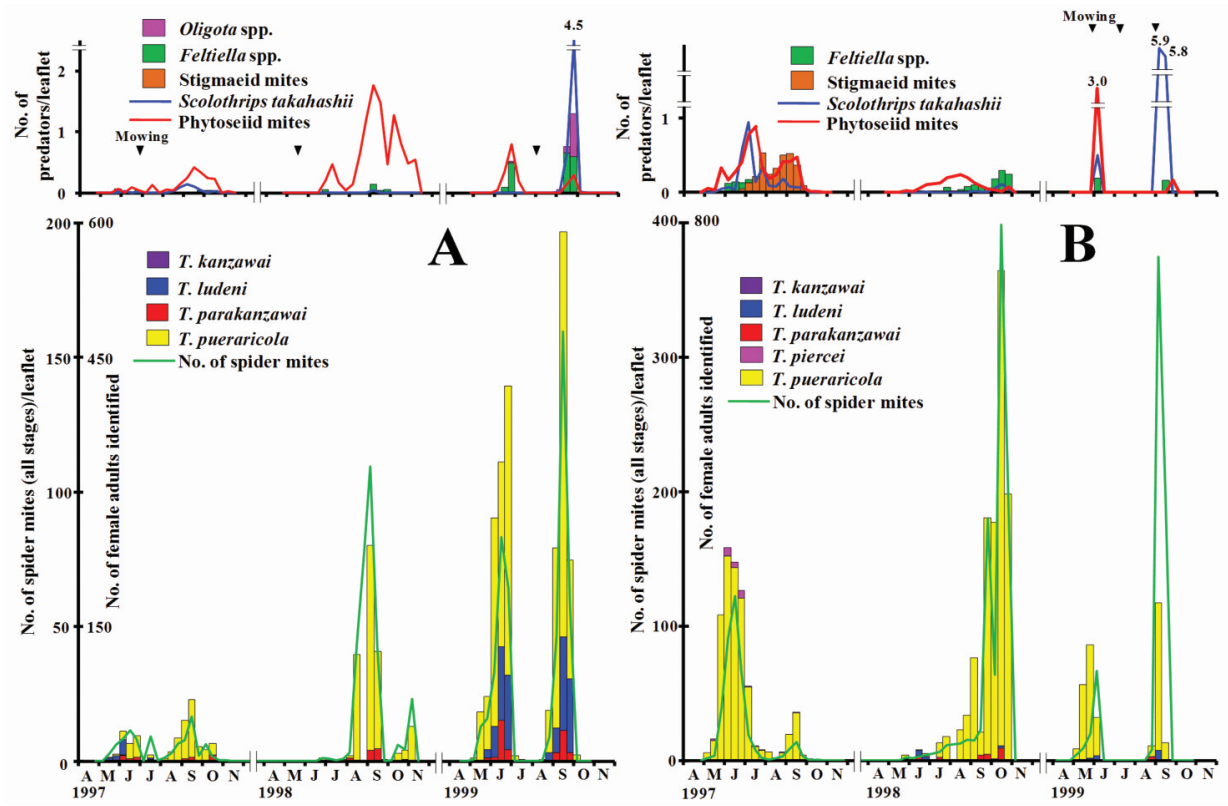

FIGURE 2. Seasonal changes in species composition and abundance of Tetranychus mites (bottom) and predatory mites (upper) on kudzu vine at site A (A) and site B (B) (Modified from Gotoh et al., 2007a).

Oligota species (Staphylinidae) and Feltiella species (Cecidomyidae). The occurrences of these predators were well synchronized with spider mite density in each of the three years. When spider mite density exceeded 100 individuals per leaflet (all stages included), insect predators were prone to appear on leaves. Of the phytoseiid mites, Amblyseius tsugawai Ehara was dominant at site A and Phytoseius nipponicus Ehara was dominant at site B, with great fluctuation in numbers between years. The next most abundant phytoseiid species were P. nipponicus at site A and Neoseiulus womersleyi (Schicha) at site B (Table 1).

Five species of Tetranychus mites were found on kudzu vine (Table 2). Tetranychus pueraricola was the dominant, accounting for $75.6-96.9 \%$ of all females. Other species found were $T$. ludeni (0.8-19.0\%), T. parakanzawai (1.1-9.7\%), T. piercei $(3.2 \%)$ and T. kanzawai $(0.2-1.3 \%)$; their densities and species richness varied from year to year and from site to site. The red form of $T$. urticae was never found.

TABLE 2. Species composition of Tetranychus mites on kudzu vine in two study sites from 1997 to 1999 in Ibaraki, central Japan. Values indicate the total number of female adults (percentage) identified at each year.

\begin{tabular}{lccccccc}
\hline \multicolumn{1}{c}{ Species } & \multicolumn{3}{c}{ Site A } & & \multicolumn{3}{c}{ Site B } \\
\cline { 2 - 4 } \cline { 7 - 8 } & $\mathbf{1 9 9 7}$ & $\mathbf{1 9 9 8}$ & $\mathbf{1 9 9 9}$ & & $\mathbf{1 9 9 7}$ & $\mathbf{1 9 9 8}$ & $\mathbf{1 9 9 9}$ \\
\hline T. pueraricola Ehara \& Gotoh & $248(80.3)$ & $524(93.7)$ & $1,724(75.6)$ & & $1,387(96.9)$ & $2,179(96.6)$ & $619(94.4)$ \\
T. ludeni Zacher & $27(8.7)$ & $1(0.2)$ & $434(19.0)$ & & $0(0.0)$ & $18(0.8)$ & $30(4.6)$ \\
T. parakanzawai Ehara & $30(9.7)$ & $33(5.9)$ & $123(5.4)$ & & $0(0.0)$ & $55(2.4)$ & $7(1.1)$ \\
T. piercei McGregor & $0(0.0)$ & $0(0.0)$ & $0(0.0)$ & & $44(3.1)$ & $0(0.0)$ & $0(0.0)$ \\
T. kanzawai Kishida & $4(1.3)$ & $1(0.2)$ & $0(0.0)$ & & $0(0.0)$ & $5(0.2)$ & $0(0.0)$ \\
Total & 309 & 559 & 2,281 & & 1,431 & 2,257 & 656 \\
\hline
\end{tabular}




\section{Seasonal changes of spider mite density and species composition on soybean}

Spider mite populations showed three peaks in 1999 (June, August and October), and two in 2001 (August and November) (Fig. 3). In 2000, the populations peaked only once (August), because soybean flowered and fruited more than one month earlier than in other years and as a result, all leaves had dropped by early October. Predators were phytoseiid and stigmaeid mites (Table 3), the most numerous being Gynaeseius liturivorus (Ehara), A. tsugawai, Neoseiulus californicus (McGregor) and N. womersleyi (phytoseiids) and Agistemus terminalis (Quayle) and A. exsertus Gonzalez (stigmaeids); predatory insects collected were S. takahashii and Feltiella species. The population density of $G$. liturivorus was positively related to the occurrence of phytophagous thrips until August, when thrips became scarce. Synchronized with spider mite density were phytoseiid mites other than G. liturivorus after August, and S. takahashii throughout the observation periods.

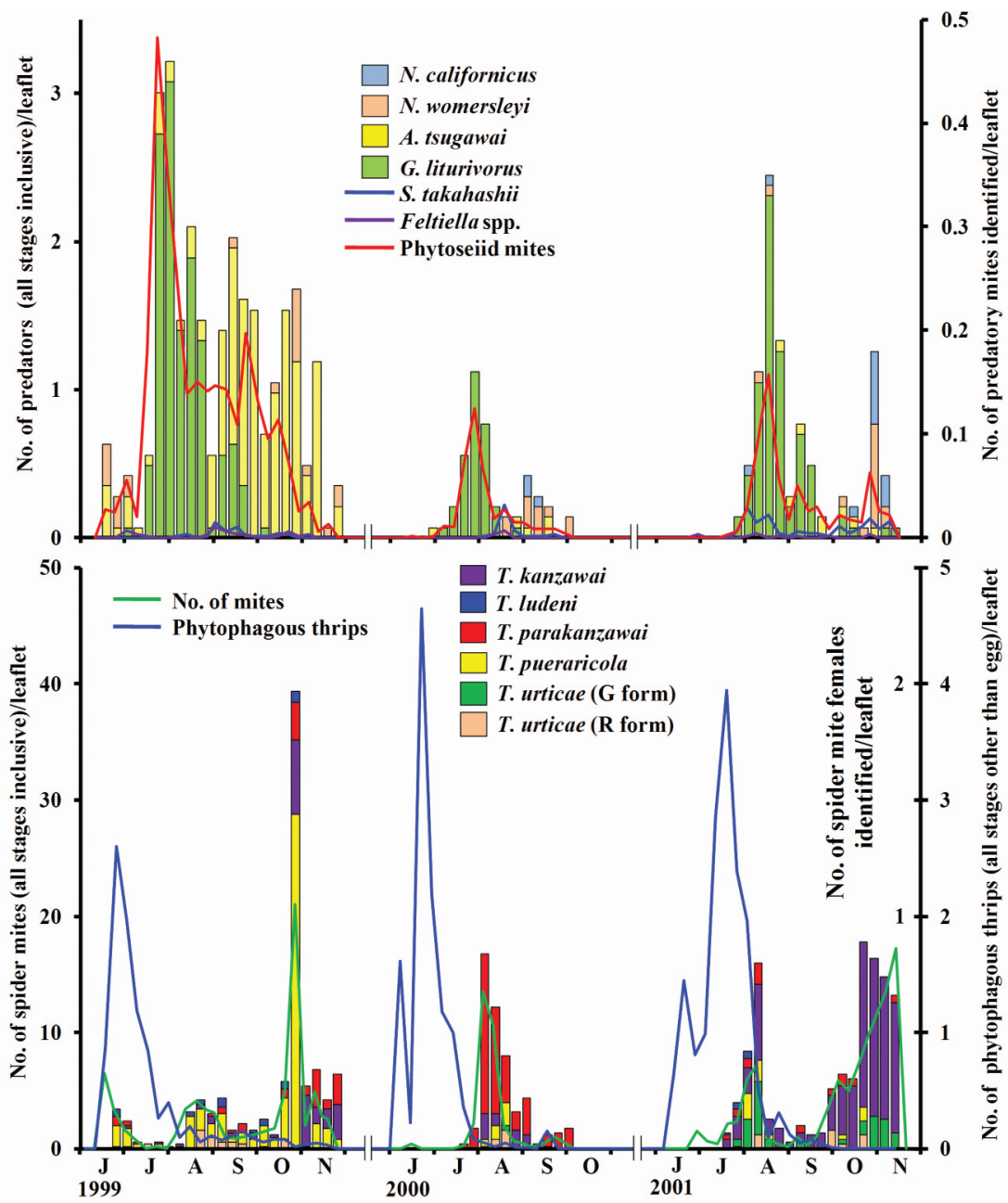

FIGURE 3. Seasonal changes in species composition and abundance of Tetranychus mites and phytophagous thrips (bottom) and predators (upper) in untreated soybean plots (i.e., plots not sprayed with any agrochemical) (Modified from Mori et al., 2008). 
TABLE 3. Phytoseiid and Stigmaeidae mites observed in soybean plots unsprayaed with agrochemicals, from 1999 to 2001 . Values indicate the total number of female adults (percentage) identified at each year.

\begin{tabular}{|c|c|c|c|}
\hline Species & 1999 & 2000 & 2001 \\
\hline \multicolumn{4}{|l|}{ Phytoseiidae } \\
\hline Gynaeseius liturivorus (Ehara) & $190(44.5)$ & $43(64.2)$ & $99(70.7)$ \\
\hline Amblyseius tsugawai Ehara & $189(44.3)$ & $5(7.5)$ & $8(5.7)$ \\
\hline Neoseiulus californicus (McGregor) & $0(0)$ & $3(4.5)$ & $13(9.3)$ \\
\hline N. womersleyi (Schicha) & $22(5.1)$ & $11(16.4)$ & $16(11.4)$ \\
\hline A. rademacheri Dosse & $1(0.2)$ & $1(1.5)$ & $1(0.7)$ \\
\hline Scapulaseius okinawanus (Ehara) & $12(2.8)$ & $1(1.5)$ & $1(0.7)$ \\
\hline A. orientalis Ehara & $3(0.7)$ & $0(0)$ & $1(0.7)$ \\
\hline A. eharai Amitai \& Swirski & $5(1.2)$ & $0(0)$ & $0(0)$ \\
\hline Euseius sojaensis (Ehara) & $0(0)$ & $0(0)$ & $0(0)$ \\
\hline N. makuwa (Ehara) & $1(0.2)$ & $0(0)$ & $0(0)$ \\
\hline Typhlodromus vulgaris Ehara & $1(0.2)$ & $1(1.5)$ & $0(0)$ \\
\hline \multicolumn{4}{|l|}{ Stigmaeidae } \\
\hline Agistemus exsertus Gonzalez & $1(0.2)$ & $0(0)$ & $0(0)$ \\
\hline A. terminalis (Quayle) & $2(0.4)$ & $2(3.0)$ & $1(0.7)$ \\
\hline Total & 427 & 67 & 140 \\
\hline
\end{tabular}

Eight spider mite species were found on soybean: T. kanzawai, T. pueraricola, T. parakanzawai, green and red forms of T. urticae, T. ludeni, T. phaselus and T. piercei (Table 4). The dominant species varied greatly from year to year. The following species were dominant most of the time: T. kanzawai (11.4-69.2\%), T. parakanzawai (5.9-72.6\%) and T. pueraricola (5.0-54.7\%).

TABLE 4. Species composition of Tetranychus mites in soybean plots unsprayed with agrochemicals, from 1999 to 2001, in Ibaraki, central Japan. Values indicate the total number of female adults (percentage) identified in each year.

\begin{tabular}{lccc}
\hline \multicolumn{1}{c}{ Species } & $\mathbf{1 9 9 9}$ & $\mathbf{2 0 0 0}$ & $\mathbf{2 0 0 1}$ \\
\hline T. kanzawai Kishida & $97(19.4)$ & $30(11.4)$ & $413(69.2)$ \\
T. pueraricola Ehara \& Gotoh & $273(54.7)$ & $20(7.6)$ & $30(5.0)$ \\
T. parakanzawai Ehara & $75(15.0)$ & $191(72.6)$ & $35(5.9)$ \\
T. urticae Koch (green form) & $0(0)$ & $3(1.1)$ & $88(14.7)$ \\
T. urticae Koch (red form) & $31(6.2)$ & $14(5.3)$ & $23(3.9)$ \\
T. ludeni Zacher & $23(4.6)$ & $0(0)$ & $7(1.2)$ \\
T. phaselus Ehara & $0(0)$ & $2(0.8)$ & $1(0.2)$ \\
T. piercei McGregor & $0(0)$ & $3(1.1)$ & $0(0)$ \\
Total & 497 & 263 & 597 \\
\hline
\end{tabular}

(After Mori et al., 2008)

\section{Discussion}

Several red-pigmented species of the genus Tetranychus can be simultaneously found on a given host plant in Japan. The enzymatic methods used in this study represent a relatively rapid and simple diagnostic procedure, similar to what was previously shown for the banding patterns of PGI and MDH (Goka \& Takafuji, 1997, 1998). Enohara \& Amano (1996) showed that esterase zymograms were useful for identifying Tetranychus species. However, esterase zymograms did not allow the discrimination of the closely related T. parakanzawai and T. kanzawai (Gotoh et al., 2007b). Despite the existence of species with polymorphic bands, PGM zymograms appear to be superior to esterase zymograms for separating seven red-pigmented mite species, including $T$. parakanzawai and T. kanzawai, because PGM had species-specific and very simple alleles. In 
addition, electrophoresis takes only $3 \mathrm{~h}$, which is comparable to the time required for PCR-RFLP analyses. Our results indicate that PGM zymograms can distinguish females of all 13 red-pigmented Tetranychus species known in Japan, even though the differences in band mobilities were sometimes small (compare adjacent species in Fig. 1).

Although previously observed on kudzu vine in Japan (Gotoh et al., 2007b), the red form of T. urticae was not found in this study. The bimodal population fluctuation pattern observed for spider mites, especially T. pueraricola, on kudzu vine is similar to what was reported for T. kanzawai on hydrangea (Gotoh \& Gomi, 2000) and the green form of T. urticae on Japanese pear (Gotoh, 1997). Spider mites on kudzu vine plummeted just after the spring peak in 1997 and 1999 at both sites. Predators were well synchronized with mite densities from May to October and many insect predators, such as S. takahashii and Feltiella species, also appeared on kudzu vine leaves. Some predatory mites such as A. tsugawai and P. nipponicus are not specific to spider mites, but feed on eriophyoid mites and pollen (McMurtry \& Croft, 1997). Unidentified eriophyoid mites appeared on kudzu vines throughout the season and grass pollen existed from mid-May to mid-July. As the populations of predatory mites and spider mites were well synchronized, it is possible that sharp declines of the spider mite population were caused by predatory mites. However, at least in part that could also be due to weed mowing. Weeds were mowed in July 1997 and July 1999 at site A and in June 1999 at site B (arrowheads in top panels of Fig. $2 \mathrm{~A}$ and $\mathrm{B}$, respectively). Mowing coincided well with the dramatic population decrease observed on kudzu vine leaves, except for the 1997 population at site A. Weeds were then irregularly mowed, causing spider mites to crowd onto surviving leaves and resulting in a small population peak in July. Population decrease of spider mite due to predation was reported in Panonychus osmanthi Ehara \& Gotoh on Osmanthus trees (Kitashima \& Gotoh, 2003). The drastic decline of spider mites did not occur at a site in which predators were removed by treating the trees with a synthetic pyrethroid, while it occurred at a site where predators were present (Kitashima \& Gotoh, 2003).

Similar population trends were observed on soybean (Fig. 3). Annual differences in spider mite species composition and density on soybean may be caused by the migration of spider mites from nearby crops and weeds to soybean. Soybean is planted in spring and harvested in autumn every year (Mori et al., 2008). As a result, spider mites on soybean are repeatedly removed from the fields in autumn and re-invade the fields in spring; which species becomes dominant is probably determined by the species that invades the soybean field first from the surrounding weeds and other crops. Proving that hypothesis would require simultaneous examination of the mite fauna on soybean and on the surrounding weeds and crops.

In conclusion, this study has demonstrated the benefits of enzymatic methods for species identification of spider mites using only adult females instead of morphological identification using both adult males and females. The procedure, especially when it is based on PGM, is rapid and reliable, and offers the opportunity to use samples from other host plants as well as any mite life stage.

Of the species tested in this study, T. pueraricola might be a candidate for control of kudzu in North America. However, this species is also able to infest some fabaceous crops (e.g., Fig. 3; Mori et al., 2008), hence its use in biological weed control requires utmost prudence. More work is needed to establish the precise conditions, if any, under which this spider mites may be recommended as a weed control agent.

\section{Acknowledgements}

We thank K. Goka for his kind cooperation with this work, and S. Abe, S. Kaibara, S. Kawai, Y. Kitashima, J. Sugasawa, A. Suwa and I. Tamura for their kind assistance during the study. 


\section{References}

Bolland, H.R., Gutierrez, J. \& Flechtmann, C.H.W. (1998) World catalogue of the spider mite family (Acari: Tetranychidae). Brill, Leiden.

Duke, J.A. \& Reed, C.F. (1981) Pueraria lobata (Willd.) Ohwi. In: Duke, J.A. (ed) Handbook of legumes of world economic importance. Plenum Press, New York, pp. 211-214.

Ehara, S. (1999) Revision of the spider mite family Tetranychidae of Japan (Acari, Prostigmata). Species Diversity, 4, 63-141.

Ehara, S. \& Gotoh, T. (2009) Colored guide to the plant mites of Japan. Zenkoku-Noson-Kyoiku-Kyokai, Tokyo [in Japanese].

Enohara, K. \& Amano, H. (1996) Simple method for discriminating six common species of red Tetranychus spider mites (Acari: Tetranychidae) in Japan. Japanese Journal of Applied Entomology and Zoology, 40, 311-315 [in Japanese].

Forester, G.J. (1993) Resource partitioning between two species of Ceutorhynchus (Coleoptera: Curculionidae) on Echinum plantagineum in a Mediterranean habitat. Bulletin of Entomological Research, $83,345-351$.

Goeden, R.D. (1971) The phytophagous insect fauna of milk thistle in southern California. Journal of Economic Entomology, 64, 1101-1104.

Goeden, R.D. (1974) Comparative survey of the phytophagous insect faunas of Italian thistle, Carduus pycnocephalus, in southern California and southern Europe relative to biological weed control. Environmental Entomology, 3, 464-474.

Goka, K. \& Takafuji, A. (1997) Identification among seven species of spider mites (Tetranychus) (Acari: Tetranychidae) based on enzyme differentiation detected by electrophoresis. Applied Entomology and Zoology, 32, 127-134.

Goka, K. \& Takafuji, A. (1998) Electrophoretic detection of enzyme variation among Japanese red-coloured spider mites of the genus Tetranychus (Acari: Tetranychidae). Experimental and Applied Acarology, $22,167-176$.

Gotoh, T. (1997) Annual life cycles of populations of the two-spotted spider mite, Tetranychus urticae Koch (Acari: Tetranychidae) in four Japanese pear orchards. Applied Entomology and Zoology, 32, 207-216.

Gotoh, T., Araki, R., Boubou, A., Migeon, A., Ferragut, F. \& Navajas, M. (2009) Evidence of co-specificity between Tetranychus evansi and Tetranychus takafujii (Acari: Prostigmata, Tetranychidae): comments on taxonomic and agricultural aspects. International Journal of Acarology, 35, 485-501.

Gotoh, T. \& Gomi, K. (2000) Population dynamics of Tetranychus kanzawai (Acari: Tetranychidae) on hydrangea. Experimental and Applied Acarology, 24, 337-350.

Gotoh, T., Gutierrez, J. \& Navajas, M. (1998) Molecular comparison of the sibling species Tetranychus pueraricola Ehara et Gotoh and T. urticae Koch (Acari: Tetranychidae). Entomological Science, 1, 55-57.

Gotoh, T. \& Ishikawa, Y. (1992) Separation of Panonychus ulmi, P. thelytokus and P. bambusicola (Acari: Tetranychidae) by esterase zymograms. Applied Entomology and Zoology, 27, 598-601.

Gotoh, T., Kaibara, S. \& Tamura, I. (2007a) Species composition and seasonal changes of spider mite density on a leguminous plant Pueraria lobata. Applied Entomology and Zoology, 42, 685-692.

Gotoh, T., Kitashima, Y. \& Goka, K. (2007b) Tetranychus mite species identification using esterase and phosphoglucomutase zymograms. Applied Entomology and Zoology, 42, 579-585.

Gotoh, T. \& Takayama, K. (1992) Developmental characteristics, genetic compatibility and esterase zymograms in three strains of the hawthorn spider mite, Tetranychus viennensis Zacher (Acari: Tetranychidae). Journal of the Acarological Society of Japan, 1, 45-60.

Hance, T., Neuberg, P. \& Noel-Lastelle, C. (1998) The use of fecundity, lobe biometry and the RAPD-PCR technique in order to compare strains of Tetranychus sp. Experimental and Applied Acarology, 22, 649-666.

Imura, O. (2003) Herbivorous arthropod community of an alien weed Solanum carolinense L. Applied Entomology and Zoology, 38, 293-300.

Japanese Society of Applied Entomology and Zoology (2006) Major insect and other pests of economic plants in Japan, Revised edition. The Japanese Society of Applied Entomology and Zoology, Tokyo [in Japanese].

Jobin, A., Schaffner, U. \& Nentwig, W. (1996) The structure of the phytophagous insect fauna on the introduced weed Solidago altissima in Switzerland. Entomologica Experimentalis et Applicata, 79, 33-42.

Kitashima, Y. \& Gotoh, T. (1997) Electrophoretic differentiation of $F_{1}$ hybrids of the sibling species Panonychus osmanthi Ehara et Gotoh and P. citri (McGregor) (Acari: Tetranychidae). Applied Entomology and Zoology, 32, 635-637.

Kitashima, Y. \& Gotoh, T. (2003) Population dynamics of Panonychus osmanthi (Acari: Tetranychidae) on two Osmanthus species. Experimental and Applied Acarology, 29, 227-240. 
McMurtry, J.A. \& Croft, B.A. (1997) Life-styles of phytoseiid mites and their roles in biological control. Annual Review of Entomology, 42, 291-321.

Mori, K., Takagi, K., Kohjimoto, T., Gotoh, T. \& Kobayashi, M. (2008) Seasonal fluctuation in population density of spider mites (Acari: Tetranychidae) and their predators on soybean cultivated in agrochemical sprayed and unsprayed plots. Japanese Journal of Applied Entomology and Zoology, 52, 215-223 [in Japanese].

Navajas, M., Gutierrez, J. \& Gotoh, T. (1997) Convergence of molecular and morphological data reveals phylogenetic information on Tetranychus species and allows the restoration of the genus Amphitetranychus (Acari: Tetranychidae). Bulletin of Entomological Research, 87, 283-288.

Navajas, M., Gutierrez, J., Williams, M. \& Gotoh, T. (2001) Synonymy between two spider mite species, Tetranychus kanzawai and T. hydrangeae (Acari: Tetranychidae), shown by ribosomal ITS2 sequences and cross-breeding experiments. Bulletin of Entomological Research, 91, 117-123.

Osakabe, M., Hirose, T. \& Sato, M. (2002) Discrimination of four Japanese Tetranychus species (Acari: Tetranychidae) using PCR-RFLP of the inter-transcribed spacer region of nuclear ribosomal DNA. Applied Entomology and Zoology, 37, 399-407.

Williamson, M. (1996) Biological invasions. Chapman \& Hall, London.

Wilson C.G. \& Flanagan, G.J. (1993) Phytophagous insect fauna of the introduced noxious weed Xanthium occidentale in northern Australia and its relevance to biological control. Environmental Entomology, $22,254-261$.

Zwölfer, H. (1988) Evolutionary and ecological relationships of the insect fauna of thistles. Annual Review of Entomology, 33, 103-122. 